\title{
Efficiency study of five blue-green algae species and two fertilizers as a source of nitrogen in the growth of rice
}

\author{
Md. Didar-ul-Alam*1 \\ ${ }^{1}$ Department of Soil Water and Environment, University of Dhaka, Dhaka-1000, Bangladesh
}

\begin{abstract}
The results for $\% \mathrm{~N}$ and $\mathrm{N}$-offtake at the first harvest the values for pots receiving $\mathrm{N}$ fertilizer were significantly higher than for those inoculated with BGA. Pots receiving $\mathrm{U}$ produced material with the higher $\mathrm{N}$-content but there was no difference between the two-fertilizer treatments in case of $\mathrm{N}$-offtake at the first harvest. Looking at the interactions the materials with the higher $\mathrm{N}$-content produced with Anabaena Varabilies and Anabaena doliolum inoculated pots at the $1^{\text {st }}$ harvest. Of the BGA treatments $\mathrm{N}$-offtake was higher in A.doliolum and A.varibilies pots at $1^{\text {st }}$ harvest. At the $2^{\text {nd }}$ harvest for both fertilizers, $\mathrm{N}$-offtake increased with $\mathrm{N}$-applied to a maximum with $120 \mathrm{mg} \mathrm{N}^{-\mathrm{p}^{-1}}$ for $\mathrm{U}$ and to minimum with $90 \mathrm{mg} \mathrm{N}$ pot $^{-1}$ for AS.
\end{abstract}

\section{Introduction}

The most important single limitation to food production is the availability to nitrogen to plants and, indirectly to animals. One-third humanity is undernourished, and at least one-half is hungry [1]. The solution has been to apply nitrogen fertilizer, produced chemically. It has been estimated that 20 percent of the global fixation of nitrogen, biological and non-biological are of direct used in agriculture. Most field experiments conducted in rice growing countries indicate that the application of organic or chemical fertilizer plays a dominant role in increasing rice yield and the efficiency of agronomic practices.

Many species of blue-green algae have the ability to fix atmospheric nitrogen [2] and thus contribute to the system. Some species of blue green algae have been reported to fix between 15 to $50 \mathrm{Kg} \mathrm{N} \mathrm{ha}^{-1}$ years ${ }^{-1}$.

It is important to acknowledge the influence of energy cost on current and probable future prices of $\mathrm{N}$ fertilizers and need to stimulate research on alternative sources of nitrogen for rice cultivation. With those ideas in view, an experiment was conducted to evaluate the specific efficiency supplying $\mathrm{N}$ by five BGA species as a source of $\mathrm{N}$ for rice production and two chemical fertilizers and compared them to $\mathrm{N}$ provided as inorganic fertilizer under greenhouse condition.

\section{Methods and materials}

The soil for the present experiment is highly productive known as Insch soil obtained from Murrials farm in aberdeenshire of Scotland UK. Chemically, the soil had $\mathrm{pH} 5.96$, organic carbon $7.95 \%$, total nitrogen $0.28 \%$, cation exchange capacity $11.5 \mathrm{meq} 100^{-1}$ and sandy loam as texture. The rice variety 'MRI' of Malaysian agricultural development Institute were 1R22 collected from school of agriculture, Aberdeen University, UK. 'MR1'was selected as indicator plant because of its high and stable yield that has poor eating quality but excellent plant type.

After viability test (98.3\% germination was recorded), the 25 days old seedlings were transplanted to pots. The experiment was laid out in a split plot design. The experimental plots were divided into two blocks representing two replications. Each block was sub-divided into sub- blocks. Each sub-block was again divided into 21 unit plots upon which the treatment was superimposed randomly. Two types of control were prepared provided in this design. One control receiving no nitrogen (0) and the second control was inoculated with five species of BGA in each sub block without growing rice plants. Thus, there were 21 treatments; the total number of unit plots (pots) was 84 . There were three sources of nitrogen, namely urea (U), ammonium sulfate (AS) @ 30,60.90,120, \& $150\left(\mathrm{mg} \mathrm{N}^{-1}\right)$ and all five blue green algae (BGA) used as the five rates. For the BGA each species was considered to be a rate by the following way (Table 1).

84 plastic $21 \times 17 \mathrm{~cm}$ round pots were numbered consecutively. Each pot was about 4-litre capacity and the drainage holes were closed with thick sticky tape. The pots were washed carefully and dried before use. $1800 \mathrm{~g}$ air-dry soil was placed into each pot with capillary matting (Fyba mat) at the bottom. The air-dry soil was mixed with $20 \mathrm{ml}$ of $\mathrm{KH}_{2} \mathrm{PO}_{4}$ solution in a Kenwood mixer for the basic fertilizer dose of $\mathrm{p}$ and $\mathrm{K}$. The moist soil was transferred to the pots with light and even packing and $1500 \mathrm{ml}$ of water were added to each pot. This forms a $2-\mathrm{cm}$ depth of standing water over the soil surface. The pots were kept

Table 1. Five species of BGA.

\begin{tabular}{|c|c|c|}
\hline Rate & Fertilizers & BGA \\
\hline & $\left(\mathrm{mg} \mathrm{N} \mathrm{pot}^{-1}\right)$ & \\
\hline 1 & 30 & Anabaena variabilies \\
\hline 2 & 60 & Anabaena cylindrica \\
\hline 3 & 90 & Anabaena doliolum \\
\hline 4 & 120 & Nostoe muscorum \\
\hline 5 & 150 & Plectonema boryanum \\
\hline
\end{tabular}

Correspondence to: Md. Didar-ul- Alam, Department of Soil Water and Environment, University of Dhaka, Dhaka-1000, Bangladesh, E-mail: dilafi@ gmail.com

Key words: N2-fixation, Interaction, and Fertilizer treatments

Received: February 09, 2017; Accepted: March 03, 2017; Published: March 07, 2017 
at constant temperature covering with polythene sheet. The pots were transformed after 5 days to the glass house and appropriate quantities of $\mathrm{N}$ fertilizer added and mixed. In case of BGA pots each inoculate was applied as a liquid suspension. Four days after transplanting, when the seedlings become fully established, the depth of standing water was raised to $4.5 \mathrm{~cm}$ and maintained through-out the growing period. In the present study, the temperature was optimum $\left(25-30^{\circ} \mathrm{C}\right)$ upto 56 days and then dropped in month November. In that month and especially on cloudy clays fluorescent lights were used to supply adequate light. The pots were weeded by hand from time to time when necessary the rice plants started tillaring within 2 weeks after transplanting. Six weeks after transplanting, pots numbering 1-21 from block I and 43-63 from block II and twelve weeks after transplanting (harvest) the plant samples were removed, washed, weighed, dried, reweigh and ground. The method of Bremner [3] was followed for nitrogen analysis.

\section{Statistical analysis}

It was necessary to calculate the standard error of differences of means (SED) for correct comparison among all treatments. The Genstat statistical computer package incorporates a split plot model consists of: $\mathrm{N}$ rates, $\mathrm{N}$-rates $\mathrm{X} \mathrm{N}$-source interaction, Harvest $\mathrm{X}$ rates, harvest $\mathrm{X}$ sources, harvest $\mathrm{X}$ Rate $\mathrm{X}$ source at two different harvest. The SED at $p \leq 0.001, p \leq 0.01, p \leq 0.05$ levels were shown in each table. In comparing those results the superscript letter before the mean indicates weather within the columns are significantly different while those following the means provide information on the significance between columns.

\section{Results and discussion}

$\mathrm{N}$ content and $\mathrm{N}$ offtake by rice following application of different rates of urea, ammonium sulfate and five BGA species at both harvest is presented in Table 2. The statistical results of $\% \mathrm{~N}$ - contents and $\mathrm{N}$-offtake of the dry matter are presented in Table 3 (a) and 3(b) respectively.

\section{N-content}

At the first harvest the $\mathrm{N}$-content of the plant material produced in pots inoculated with BGA were significantly lower than those receiving nitrogen fertilizers. Pots receiving Urea produced material with the higher $\mathrm{N}$ - content and looking at the interactions the materials with the higher $\mathrm{N}$-content produced from BGA inoculum were the pots inoculated with Anabaena variabilies and Anabaena doliolum i.e. those pots with the highest dry matter yields. The plants growing in pots receiving Urea showed increasing N- content upto rate 3 (90 mg N pot $\left.^{-1}\right)$. The values for the material receiving AS were more variable but showed a similar trend. At the second harvest, there was no difference in the $\mathrm{N}$ - contents of the plant material produced by BGA inoculation or by fertilizer application. This probably reflects the difference in dry matter production and can be explained by examining the $\mathrm{N}$-offtake results (Table 2). Looking at the interactions there is little difference between $\mathrm{N}$ - contents of the plant material produced by the different treatments but where As was applied $\mathrm{N}$-content does increase with increasing $\mathrm{N}$ addition.

\section{N-offtake}

The values for pot receiving $\mathrm{N}$-fertilizer where significantly higher than those inoculated with BGA at the first harvest but there was no difference between the two fertilizer treatments (Table 3(b)). Of the BGA treatments N-offtake was higher where A.doliolum and A.variabilies were used but significantly lowers where N.muscorum was used. There is a discernible trend where AS was applied showing increasing $\mathrm{N}$-offtake with increasing $\mathrm{N}$-applied.

At the second harvest, bigger differences were observed. N-offtake was significantly lower in pots inoculated with BGA compared to those receiving fertilizers and of the two fertilizers treatments, offtake was significantly higher from pots receiving $U$ compared to AS. Of the BGA-inoculated pots, the highest $\mathrm{N}$-offtake was obtained where A.variabilies and A.cylindrica were inoculated and lowest where P.boryanum was inoculated. There was a difference in the pattern of $\mathrm{N}$-offtake results compared to the first harvest. More obvious trends were identified where $\mathrm{N}$-fertilizer was applied. For both fertilizers, $\mathrm{N}$-offtake increased with $\mathrm{N}$-applied to a maximum with rate $4(120$ $\mathrm{mg} \mathrm{N}$ pot $^{-1)}$ for $\mathrm{U}$ application and to maximum with rate $3(90 \mathrm{mg}$ $\mathrm{N}$ pot $^{-1}$ ) for AS.

Table 2. Dry matter yield, N- content and N-offtake by rice are expressed as percentage of dry matter $(\mathrm{dm})$ in duplicate values at $1^{\text {st }}$ and $2^{\text {nd }}$ harvest.

\begin{tabular}{|c|c|c|c|c|c|c|c|c|c|c|c|c|c|}
\hline \multicolumn{7}{|c|}{$1^{\text {st }}$ Harvest } & \multicolumn{7}{|c|}{$2^{\text {nd }}$ Harvest } \\
\hline \multirow{2}{*}{$\begin{array}{c}\text { Treatments } \\
6 \\
\end{array}$} & \multicolumn{2}{|c|}{$\begin{array}{l}\text { Dry matter yield(dm), } \\
\text { g pot- } 1\end{array}$} & \multicolumn{2}{|c|}{$\mathrm{N} \%$} & \multicolumn{2}{|c|}{$\begin{array}{l}\mathrm{N} \text { offtake } \\
\text { mg pot-1 }\end{array}$} & \multirow{2}{*}{\begin{tabular}{|c|} 
Treatments \\
6
\end{tabular}} & \multicolumn{2}{|c|}{$\begin{array}{l}\text { Dry matter yield(dm),g } \\
\text { pot-1 }\end{array}$} & \multicolumn{2}{|c|}{$\mathrm{N} \%$} & \multicolumn{2}{|c|}{$\begin{array}{l}\mathrm{N} \text { offtake } \\
\text { mg pot-1 }\end{array}$} \\
\hline & 0.87 & 1.01 & 2.48 & 2.43 & 21.6 & 24.5 & & 3.53 & 3.74 & 1.40 & 1.46 & 49.4 & 50.9 \\
\hline 7 & 1.93 & 2.08 & 3.00 & 2.93 & 57.9 & 60.9 & 7 & 5.90 & 5.73 & 1.46 & 1.62 & 86.1 & 92.8 \\
\hline 8 & 1.79 & 1.87 & 3.38 & 3.48 & 60.5 & 65.1 & 8 & 5.15 & 5.42 & 1.17 & 1.22 & 60.3 & 66.1 \\
\hline 9 & 1.25 & 1.37 & 3.19 & 3.12 & 39.9 & 42.7 & 9 & 5.74 & 5.58 & 1.00 & 1.10 & 57.4 & 61.4 \\
\hline 10 & 1.56 & 1.66 & 2.70 & 2.65 & 42.1 & 44.0 & 10 & 4.39 & 4.58 & 1.89 & 1.80 & 82.9 & 82.4 \\
\hline 11 & 1.63 & 1.71 & 3.63 & 3.52 & 59.2 & $60 . .2$ & 11 & 4.57 & 4.76 & 1.63 & 1.60 & 74.5 & 76.1 \\
\hline 12 & 1.88 & 1.96 & 3.18 & 3.07 & 59.8 & 60.2 & 12 & 4.36 & 4.45 & 1.92 & 1.85 & 82.7 & 82.3 \\
\hline 13 & 1.96 & 2.01 & 3.40 & 3.29 & 66.6 & 66.1 & 13 & 4.19 & 4.31 & 1.78 & 1.73 & 74.6 & 74.6 \\
\hline 14 & 1.70 & 1.76 & 3.28 & 3.17 & 55.8 & 55.2 & 14 & 6.13 & 6.30 & $1 / 72$ & 1.61 & 105.4 & 101.4 \\
\hline 15 & 1.27 & 1.41 & 3.36 & 3.29 & 42.7 & 46.4 & 15 & 6.24 & 6.33 & 1.68 & 1.60 & 104.8 & 101.3 \\
\hline 16 & 1.12 & 1.05 & 2.51 & 2.51 & 29.1 & 26.4 & 16 & 3.99 & 4.25 & 1.49 & 1.52 & 59.6 & 64.6 \\
\hline 17 & 1.50 & 1.45 & 3.15 & 3.15 & 47.6 & 45.7 & 17 & 5.89 & 5.72 & 2.05 & 1.94 & 120.7 & 110.7 \\
\hline 18 & 1.96 & 1.83 & 3.21 & 3.21 & 63.9 & 58.7 & 18 & 6.32 & 5.97 & 1.42 & 1.34 & 89.7 & 80.0 \\
\hline 19 & 1.53 & 1.62 & 2.51 & 2.51 & 39.2 & 40.7 & 19 & 4.06 & 4.25 & 1.30 & 1.37 & 52.8 & 58.2 \\
\hline 20 & 1.79 & 1.92 & 3.90 & 3.90 & 69.5 & 75.3 & 20 & 6.97 & 6.20 & 1.80 & 1.72 & 107.8 & 106.6 \\
\hline 21 & 2.27 & 2.33 & 3.76 & 3.76 & 85.8 & 87.6 & 21 & 4.89 & 5.02 & 2.03 & 1.94 & 99.7 & 97.4 \\
\hline
\end{tabular}


Didar-ul-Alam M (2017) Efficiency study of five blue-green algae species and two fertilizers as a source of nitrogen in the growth of rice

Table 3 (a). $\mathrm{N}$ offtake by rice as obtained by application of different species of BGA and rates of sulphate and urea at. $1^{\text {st }}$ harvest.

\begin{tabular}{|c|c|c|c|c|c|c|c|}
\hline \multirow[b]{2}{*}{$\mathrm{N}$-rates( R ) } & \multicolumn{7}{|c|}{$\begin{array}{c}\text { Treatment means } \\
1^{\text {st }} \text { harvest }\end{array}$} \\
\hline & 1 & 2 & 3 & 4 & 5 & SED & $\begin{array}{l}\text { Significance of } \\
\text { difference }\end{array}$ \\
\hline & $54.50^{\mathrm{b}}$ & $54.25^{\mathrm{b}}$ & $55.47^{\mathrm{b}}$ & $45.25^{\mathrm{a}}$ & $61.35^{\mathrm{c}}$ & 3207 & $\mathrm{P} \leq 0.01$ \\
\hline & & $\begin{array}{c}\mathrm{b}=0.05 \\
\mathrm{c}=0.1\end{array}$ & & & & & \\
\hline \multirow[t]{3}{*}{$\mathrm{N}$-sources (S) } & BGA & $\mathrm{U}$ & AS & & & & \\
\hline & $47.30^{\mathrm{a}}$ & $59.41^{\mathrm{b}}$ & $55.77^{\mathrm{b}}$ & & & 2.484 & $\mathrm{P} \leq 0.01$ \\
\hline & & $\mathrm{b}=0.01$ & & & & & \\
\hline RXS N-Sources rate & BGA & $\mathrm{U}$ & AS & & & & \\
\hline $0($ Control $)$ & & - & - & & 23.08 & & \\
\hline 1 & ${ }^{\mathrm{c}} 59.4^{\mathrm{b}}$ & ${ }^{\mathrm{a}} 62.8^{\mathrm{b}}$ & ${ }^{\mathrm{a}} 41.3^{\mathrm{a}}$ & $\mathrm{b}=0.01$ & & 5.55 & $\mathrm{P} \leq 0.001$ \\
\hline 2 & ${ }^{\mathrm{b}} 43.1^{\mathrm{a}}$ & a $59.7^{b}$ & ${ }^{\mathrm{b}} 60.0^{\mathrm{b}}$ & $\mathrm{b}=0.01$ & & & \\
\hline 3 & ${ }^{\mathrm{c}} 66.4^{\mathrm{c}}$ & ${ }^{\mathrm{a}} 55.5^{\mathrm{b}}$ & ${ }^{\mathrm{a}} 44.6^{\mathrm{a}}$ & $\begin{array}{l}\mathrm{b}=0.1 \\
\mathrm{c}=0.1\end{array}$ & & & \\
\hline 4 & a $27.8^{\mathrm{a}}$ & ${ }^{\mathrm{a}} 46.7^{\mathrm{b}}$ & ${ }^{\mathrm{b}} 61.3^{\mathrm{c}}$ & $\mathrm{b}=0.01 \mathrm{c}=0.05$ & & & \\
\hline \multirow[t]{2}{*}{5} & ${ }^{\mathrm{b}} 40.0^{\mathrm{a}}$ & $\mathrm{a} 72.4^{\mathrm{b}}$ & $\mathrm{a} 71.7^{\mathrm{b}}$ & $\mathrm{b}=0.001$ & & & \\
\hline & $\begin{array}{l}\mathrm{b}=0.05 \\
\mathrm{c}=0.05\end{array}$ & $\mathrm{a}=\mathrm{n} \cdot \mathrm{s}$ & $\begin{array}{c}\mathrm{a}=\mathrm{n} . \mathrm{s} \\
\mathrm{b}=0.05 \\
\mathrm{c}=0.1\end{array}$ & & & & \\
\hline
\end{tabular}

Table 3 (b). $\mathrm{N}$ offtake by rice as obtained by application of different species of BGA and rates of sulphate and urea at $2^{\text {nd }}$ harvest.

\begin{tabular}{|c|c|c|c|c|c|c|c|}
\hline \multicolumn{8}{|c|}{$\begin{array}{l}\text { Treatment means } \\
2^{\text {nd }} \text { harvest }\end{array}$} \\
\hline \multirow[b]{2}{*}{ N-rates (R) } & 1 & 2 & 3 & 4 & 5 & SED & $\begin{array}{l}\text { Significance of } \\
\text { difference }\end{array}$ \\
\hline & $70.7^{\mathrm{a}}$ & $\begin{array}{c}80.32^{b} \\
b=0.001 \\
c=0.01 \\
d=0.01\end{array}$ & $93.68^{d}$ & $\begin{array}{c}87.55^{\mathrm{c}} \\
\mathrm{c}=0.01\end{array}$ & $87.04^{\mathrm{c}}$ & 1.902 & $\mathrm{P} \leq 0.001$ \\
\hline \multirow[b]{2}{*}{ N-sources(S) } & BGA & $\mathrm{U}$ & AS & & & & \multirow[b]{2}{*}{$\mathrm{P} \leq 0.001$} \\
\hline & $72.87^{\mathrm{a}}$ & $\begin{array}{c}92.93^{c} \\
b=0.001 \\
c=0.001\end{array}$ & $85.77^{\mathrm{b}}$ & & & 1.474 & \\
\hline RXS N-Sources rates & BGA & $\mathrm{U}$ & AS & & & & \multirow{7}{*}{$\mathrm{P} \leq 0.001$} \\
\hline 0 ( Control) & - & - & - & 50.25 & & & \\
\hline 1 & ${ }^{\mathrm{e}} 89.5^{\mathrm{b}}$ & ${ }^{\mathrm{a}} 63.20^{\mathrm{a}}$ & ${ }^{\mathrm{a}} 59.20^{\mathrm{a}}$ & $\mathrm{b}=0.001$ & & \multirow{5}{*}{3.295} & \\
\hline 2 & ${ }^{\mathrm{d}} 82.65^{\mathrm{b}}$ & ${ }^{\mathrm{b}} 73.30^{\mathrm{a}}$ & ${ }^{\mathrm{b}} 83.0^{\mathrm{b}}$ & $\mathrm{b}=0.05$ & & & \\
\hline \multirow[t]{2}{*}{3} & ${ }^{\mathrm{c}} 74.60^{\mathrm{a}}$ & ${ }^{\mathrm{c}} 103.40^{\mathrm{b}}$ & ${ }^{\mathrm{c}} 103.05^{\mathrm{b}}$ & $\mathrm{b}=0.001$ & & & \\
\hline & ${ }^{\mathrm{b}} 62.10^{\mathrm{a}}$ & ${ }^{\mathrm{d}} 115.70^{\mathrm{c}}$ & ${ }^{\mathrm{b}} 84.85^{\mathrm{b}}$ & $\begin{array}{l}\mathrm{b}=0.001, \\
\mathrm{c}=0.001 .\end{array}$ & & & \\
\hline 5 & $\begin{array}{c}{ }^{\mathrm{a}} 55.52^{\mathrm{a}} \\
\mathrm{b}=0.1 \\
\mathrm{c}=0.01 \\
\mathrm{~d}=0.05 \\
\mathrm{e}=0.1\end{array}$ & $\begin{array}{l}{ }^{c} 107.05^{c} \\
b=0.01 \\
c=0.001 \\
d=0.05\end{array}$ & $\begin{array}{c}\mathrm{c} 98.55^{\mathrm{b}} \\
\mathrm{b}=0.001 \\
\mathrm{c}=0.001\end{array}$ & $\begin{array}{c}\mathrm{b}=0.001 \\
\mathrm{c}=0.05\end{array}$ & & & \\
\hline
\end{tabular}

+ abcde means bearing the different superscripts differ significantly at $\mathrm{P} \leq 0.001, \mathrm{P} \leq 0.01$, and $\mathrm{P} \leq 0.05$

+ All SED's are against $15 \mathrm{df}$.

\section{References}

1. Mason J (1989) Nitrogen fixation problem. The Open University, Inorganic Chemistry, S343, Block 7.
2. Lund JWG (1967) Soil algae in Soil Biology (A Burges and F. Raw, ed.) pp.129-147. Academic Press New York.

3. Bremner JM (1965) Inorganic forms of nitrogen in "Methods of Soil analysis" (C.A.Black, Ed), Agronomy No 9, Chapter 84 (Part 2) pp.1179-127. Amer Soc Agron, Madison, Wisconsin.

Copyright: (C2017 Didar-ul-Alam M. This is an open-access article distributed under the terms of the Creative Commons Attribution License, which permits unrestricted use, distribution, and reproduction in any medium, provided the original author and source are credited. 